\section{Evaluation of Water-Air Balance of Various Substrates on Begonia Growth}

\author{
Paraskevi A. Londra ${ }^{1}$ \\ Department of Natural Resources Management and Agricultural Engineering, \\ Agricultural University of Athens, 75, Iera Odos, 11855, Athens, Greece
}

Angeliki T. Paraskevopoulou

Department of Floriculture and Landscape Architecture, Agricultural University of Athens, 75, Iera Odos, 11855, Athens, Greece

\author{
Maria Psychoyou \\ Department of Natural Resources Management and Agricultural Engineering, \\ Agricultural University of Athens, 75, Iera Odos, 11855, Athens, Greece
}

Additional index words. evapotranspiration, water retention curve, substrate oxygen concentration, plant growth

\begin{abstract}
The water-air balance of four soilless substrates: $75 \%$ sphagnum peat-25\% perlite $\left(\mathrm{Ps}_{75}: \mathrm{P}_{\mathbf{2 5}}\right), \mathbf{5 0 \%}$ sphagnum peat-50\% perlite $\left(\mathrm{Ps}_{50}: \mathrm{P}_{\mathbf{5 0}}\right), \mathbf{5 0 \%}$ coir-50\% perlite $\left(\mathrm{C}_{50}: \mathrm{P}_{50}\right)$, and a fortified substrate with $60 \%$ sphagnum peat $-30 \%$ black peat-10\% perlite $\left(\mathrm{Ps}_{60}: \mathrm{Pb}_{30}: \mathrm{P}_{10}\right)$ (in a volumetric proportion) was investigated under two different irrigation methods (drip and sub-irrigation), and its effect on the growth of Begonia $\times$ elatior 'The President' was studied. The bulk density, particle size distribution, and water retention curve of the substrates were determined. Furthermore, the water profiles, oxygen $\left(\mathrm{O}_{2}\right)$ concentration, and $\mathrm{O}_{2}$ diffusion rate of all substrates were determined during a 16-week cultivation period. Plant height, flower production, and both shoot and root dry weights as well as percent growth increase of plants were measured at the end of the experiment. The substrate water profiles showed that the water content was greater and air content was less in substrates of pots irrigated with drip irrigation than with sub-irrigation. The $\mathrm{O}_{2}$ concentration in all substrates irrespective of the irrigation method was high. The $\mathrm{O}_{2}$ diffusion rate values of sub-irrigated substrates were greater than those drip-irrigated, and $\mathrm{Ps}_{60}: \mathrm{Pb}_{30}: \mathrm{P}_{10}$ showed the greatest values. Shoot and root dry weights and percent growth increase of drip-irrigated plants were greater than that of sub-irrigated plants.
\end{abstract}

In an effort to improve the physicalhydraulic properties of substrates, either pure organic materials such as peat, coir, etc., or mixes at various proportions with other organic or inorganic materials (e.g., perlite) are used to compose a substrate. In recent years, soilless substrates have been more widely used for growing pot plants because of several advantages that include facilitated root penetration, reduced levels of pathogenic microorganisms, absence of weeds, light weight, high water capacity, and high water retention capacity.

Among organic materials used as substrates, peat is the most widely distributed worldwide (Bunt, 1988; Heiskanen, 1993; Puustjärvi, 1977) with many desirable characteristics such as both high cation exchange capacity and water retention capacity and resistance to decomposition (Nelson, 2011). However, coir (coconut coir dust) is reported to have

\footnotetext{
Received for publication 29 Nov. 2011. Accepted for publication 14 Apr. 2012.

We thank KITANTZIS group of companies for the donation of the plants and substrates used in this study.

${ }^{1}$ To whom reprint requests should be addressed; e-mailv.londra@aua.gr.
}

many characteristics that make it equal or superior to peat as a component in substrates (Arenas and Vavrina, 1998; Cresswell, 1992; Evans et al., 1996; Meerow, 1994; Stamps and Evans, 1997).

During irrigation of organic substrates (i.e., peat, coir), as the amount of water increases, root aeration decreases as a result of the large water retention capacity of these substrates, which render them extremely difficult in retaining a sufficient water-air balance (De Boodt and Verdonck, 1972; Heiskanen, 1993; Puustjärvi, 1977). As a result, organic substrates are mixed with inorganic materials such as coarse sand, perlite, etc., with an aim to improve substrate aeration and physical properties (Bunt, 1988; Heiskanen, 1995a, 1995b; Nektarios et al., 2011a, 2011b).

Begonia is a species sensitive to soil moisture and demanding to soil oxygen concentration (Johnson, 1968). The root system is easily damaged by irregular moisture levels of substrates. Substrates suitable for the root growth of begonias require at least $10 \%$ to $20 \%$ air-filled porosity (Johnson, 1968). Drip irrigation and capillary mat sub-irrigation are the most common irrigation methods for begonia production.

In this article, the water-air balance of four soilless substrates on the growth of
Begonia $\times$ elatior 'The President' was investigated under two different irrigation methods used widely in begonia production.

\section{Materials and Methods}

Plant materials. Begonias (Begonia $\times$ elatior 'The President') were grown in pots in four different substrates under two watering regimes. The experiment took place in a glass greenhouse at the Agricultural University of Athens that included a heating source and ventilation system, which maintained humidity and temperature levels ideal for plant development. Daily temperatures ranged between 20 and $35{ }^{\circ} \mathrm{C}$ during the day and $\approx 12{ }^{\circ} \mathrm{C}$ during the night. Daily humidity ranged between $30 \%$ and $60 \%$ during the day and $90 \%$ during the night.

In response to photoperiod, begonia is a short-day plant and requires 2 weeks of short days to commence flowering (Hilding, 1982; Molnar, 1974). Therefore, the following photoperiod management was applied throughout the duration of the experiment (i.e., 16 weeks): 1) initial 4 weeks long day (14 to $16 \mathrm{~h}$ ); 2) following 2 weeks short day (9 to $10 \mathrm{~h}$ ); and 3) following 8 weeks long day. Lighting was provided to cover additional needs when required. Lighting was installed for lengthening the daylength when required, which included four fluorescent lamps (TLD 33; Philips, The Netherlands), providing a light intensity of $22.5 \mu \mathrm{mol} \cdot \mathrm{m}^{-2} \cdot \mathrm{s}^{-1}$.

Irrigation facilities. In the surface irrigation method, two drippers were installed opposite each other at the surface of each pot, whereas in the sub-irrigation method, two drippers were installed adjacent to the base of each pot on a capillary mat lined with a waterproof polyvinyl chloride sheet to maintain saturation. Two irrigation regimes were applied to drip-irrigated pots: in the first irrigation regime, between $4 \mathrm{Dec}$. and 31 Jan. the next year, $200 \mathrm{~cm}^{3}$ of water was applied to each pot at $50 \mathrm{~cm}$ water tension. In the second irrigation regime, between 1 Feb. and 30 Mar., the plants were larger in size and had greater irrigation requirements. Therefore, irrigation was applied daily at amounts determined by pot weighing that ranged between 70 and $100 \mathrm{~g}$ equivalent to 2.63 and $3.76 \mathrm{~mm} \cdot \mathrm{d}^{-1}$, respectively. These amounts were confirmed by the corresponding water profiles. With regard to sub-irrigation, capillary mat saturation was accomplished daily by irrigating three times at 1-h intervals

Uniform begonia plants supplied by a local nursery were individually planted (4 Dec.) in small pots (height $11.9 \mathrm{~cm}$ and volume $1442 \mathrm{~cm}^{3}$ ) and 5 weeks later (8 Jan.) were replanted in larger pots (height $19.9 \mathrm{~cm}$ and volume $4938 \mathrm{~cm}^{3}$ ) where they remained until the end of the experiment (30 Mar.). One set of 40 plants planted in four substrates (10 plants for each substrate, $\mathrm{n}=10$ ) received drip irrigation and another set received sub-irrigation.

Substrate materials. The substrates selected for the study (on a volume basis) consisted of: 1) $75 \%$ Lithuanian sphagnum peat and $25 \%$ floriculture perlite $\left.\left(\mathrm{Ps}_{75}: \mathrm{P}_{25}\right) ; 2\right) 50 \%$ Lithuanian sphagnum peat and $50 \%$ floriculture 
perlite $\left.\left(\mathrm{Ps}_{50}: \mathrm{P}_{50}\right) ; 3\right) 50 \%$ coir, a byproduct of coconut husk fiber treatment in compressed form with dimensions $20 \times 10 \times 5 \mathrm{~cm}$ and $50 \%$ floriculture perlite $\left(\mathrm{C}_{50}: \mathrm{P}_{50}\right)$; and 4$)$ a commercially available fortified mix widely used by professional horticulture producers in Greece that constitutes a mixture of $60 \%$ Lithuanian sphagnum peat, $30 \%$ black peat, and $10 \%$ perlite enriched with macro- and microelements $\left(\mathrm{Ps}_{60}: \mathrm{Pb}_{30}: \mathrm{P}_{10}\right)$. The $\mathrm{pH}$ of all substrates was adjusted to 5.5 to 6.0 with the addition of $\mathrm{CaCO}_{3}$. The amounts applied were $320 \mathrm{~g}$ for $\mathrm{Ps}_{75}: \mathrm{P}_{25}$ and $\mathrm{Ps}_{50}: \mathrm{P}_{50}$ and $100 \mathrm{~g}$ for $\mathrm{Ps}_{60}: \mathrm{Pb}_{30}: \mathrm{P}_{10}$.

Cultivation practices. All plants within each irrigation system received the same cultivation procedures (i.e., applications of fertilizer, fungicide, etc.). Throughout the duration of the experiment, all plants received regularly a soluble $20 \mathrm{~N}-8.7 \mathrm{P}-16.6 \mathrm{~K}$ fertilizer at $136 \mathrm{mg} \cdot \mathrm{L}^{-1} \mathrm{~N}$, fortified with micronutrients (Rosso; ALFA Agricultural Supplies S.A., Greece).

Plant growth. After 16 weeks (30 Mar.), plants were harvested at the soil level, divided into shoot and root, and the roots were washed clean from the substrate. Shoot and roots were weighed separately for their fresh weight and then placed in an oven at $70^{\circ} \mathrm{C}$ for $48 \mathrm{~h}$ and subsequently dry weighed $(\mathrm{n}=10)$. Plant height (determined from the pot rim of the substrate surface), number of flowers per plant, both shoot and root dry weights, and percent growth increase were investigated. The percent growth increase was calculated as the difference between the total plant dry weight at the start of the experiment and 16 weeks later divided by the total dry weight at the end of the experiment $(\mathrm{n}=10)$.

Substrate physical-hydraulic properties measurements. Water retention curve measurements were performed on a tension plate apparatus in a Haines-type assembly (Haines, 1930) with an air-entry value of $-190 \mathrm{~cm}$ of a water column. Substrate samples $\approx 3 \mathrm{~cm}$ in height and $18.4 \mathrm{~cm}$ in diameter, which approximated the pot diameter used in the experiment, were gradually put on the vibrating porous plate of a Buchner filter funnel to achieve satisfactory packing and subsequently subjected to gradual wetting from the bottom of the plate until saturation (for $48 \mathrm{~h}$ ). Samples were subjected to a drying-wetting cycle to obtain water contents at different pressure heads $(\mathrm{n}=3)$.

The bulk density of each substrate sample was determined for the volume obtained immediately after the last measurement of the water retention curve and drying in an oven for $48 \mathrm{~h}$ at $105^{\circ} \mathrm{C}(\mathrm{n}=3)$.

The particle size distributions of the substrates were determined by screen analysis. Weighed samples of substrates were placed on the top of a series of sieves of $0.068,0.125$, $0.25,0.50,1.00,2.00,4.00$, and $8.00-\mathrm{mm}$ screen mesh sizes arranged according to decreasing aperture and rested on a sieve shaker for $3 \mathrm{~min}$ at 30 shakes per minute $(\mathrm{n}=3)$.

Throughout the experiment, to ensure uniform growth conditions of plants in both small and large pots, the substrate moisture, evapotranspiration, and $\mathrm{O}_{2}$ levels were monitored. Substrate moisture and evapotranspiration were measured daily by tensiometers and weighing pots. To measure the changes in moisture at various depths of the substrates, a specialized device was constructed. It consisted of four mercury tensiometers in a circular arrangement positioned depending on the pot size at either two or four different heights (i.e., $1.4 \mathrm{~cm}$ and $4 \mathrm{~cm}$ for small pots and $1.4 \mathrm{~cm}, 4 \mathrm{~cm}, 8 \mathrm{~cm}$, and $12 \mathrm{~cm}$ for large pots) from the base of the pots. This device had a system of refill with water and removal of air bubbles from the tensiometers (Fig. 1). Twenty-four devices of tensiometers were used and positioned randomly in three pots for each combination of substrate and watering regime $(n=3)$.

Each tensiometer reading corresponds to water content of the substrate. Specifically, from the tensiometer readings of the water retention curve, the water content values for each substrate were determined. Daily pot

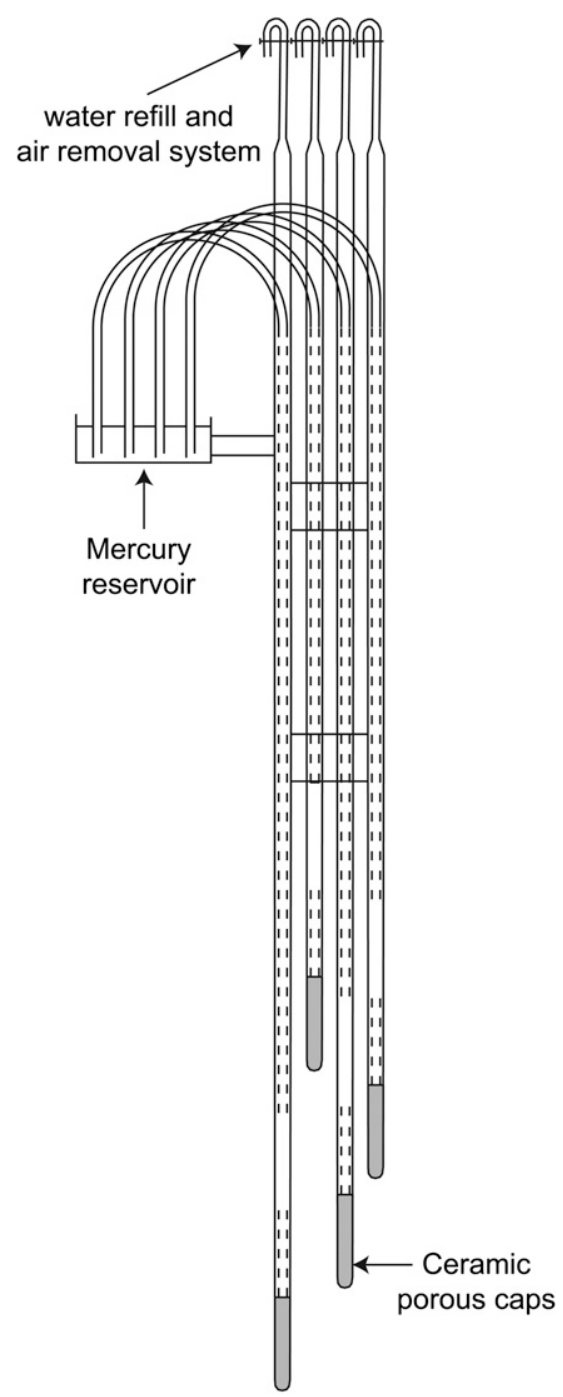

Fig. 1. Device of four mercury tensiometers positioned in a circular arrangement at four different heights with a water refill and air removal system. weighing determined the daily water requirements of the plants.

Substrate oxygen concentration and oxygen diffusion rate measurements. Oxygen concentrations of substrates were determined along the depth of the pots using a portable gas analyser (multi gas analyzer LMSx; Eijkelkamp, The Netherlands). Air samples along the depth of the pots were extracted by perforated chambers, constructed specifically for the experiment, into acrylic tubes. Each tube consisted of three chambers with perforated walls. The perforated walls of each chamber were lined on the exterior with a mesh that facilitated air passage while maintaining a porous continuum and preventing blockage of the perforated walls by substrate particles. Air was extracted and directly analyzed from the LMSx through a $1.5-\mathrm{mm}$ (internal) diameter transparent polyvinyl chloride tube positioned at the center of each chamber (Fig. 2). During the first phase of the experiment with the begonias growing in small pots, a $1.3-\mathrm{cm}$ (internal) diameter and $13 \mathrm{~cm}$ in length tube was used. Therefore, three $1 \mathrm{~cm}$ in height chambers were created with a volume size of $1.33 \mathrm{~cm}^{3}$ each and spaced at $2.5 \mathrm{~cm}$ between centers. The perforated wall of the first chamber from the substrate surface was lined with a 30 -mesh screen, whereas the other two remaining chambers were lined with a 40-mesh screen.

In the second phase of the experiment when plants were transplanted into larger pots, a $2.5-\mathrm{cm}$ (internal) diameter and $25-\mathrm{cm}$ length tube was used. Like in the previous phase, three $1-\mathrm{cm}$ height chambers were created with a volume size of $4.91 \mathrm{~cm}^{3}$ each and spaced at $5 \mathrm{~cm}$ between centers. A 30-mesh screen was placed in each of the first two chambers from the substrate surface, whereas a 40-mesh screen was placed in the last chamber.

Therefore, $\mathrm{O}_{2}$ concentrations were measured for the small pots at the following heights from the base: $2.5 \mathrm{~cm}, 5 \mathrm{~cm}$, and $7.5 \mathrm{~cm}$, whereas for the large pots, the following heights were used: $5 \mathrm{~cm}, 10 \mathrm{~cm}$, and $15 \mathrm{~cm}$ $(\mathrm{n}=10)$

Furthermore, throughout the duration of the experiment, the rate of oxygen diffusion was measured with an electrode device $(\mathrm{n}=10)$ (oxygen diffusion rate meter; Eijkelkamp).

Statistical analysis. The experiment followed the split plot design. The different types of irrigation methods were randomly assigned to main plots, whereas the different types of substrates were randomly assigned to subplots within each main plot. The analysis of variance was performed using JMP (SAS Inst., Cary, NC) statistical software and treatment means were compared using Tukey-Kramer's test at a probability level $P=0.05$.

\section{Results and Discussion}

Physical-hydraulic properties of substrates. According to De Boodt and Verdonck (1972), water retention in substrates with a pressure head more negative than $-100 \mathrm{~cm}$ decreases 


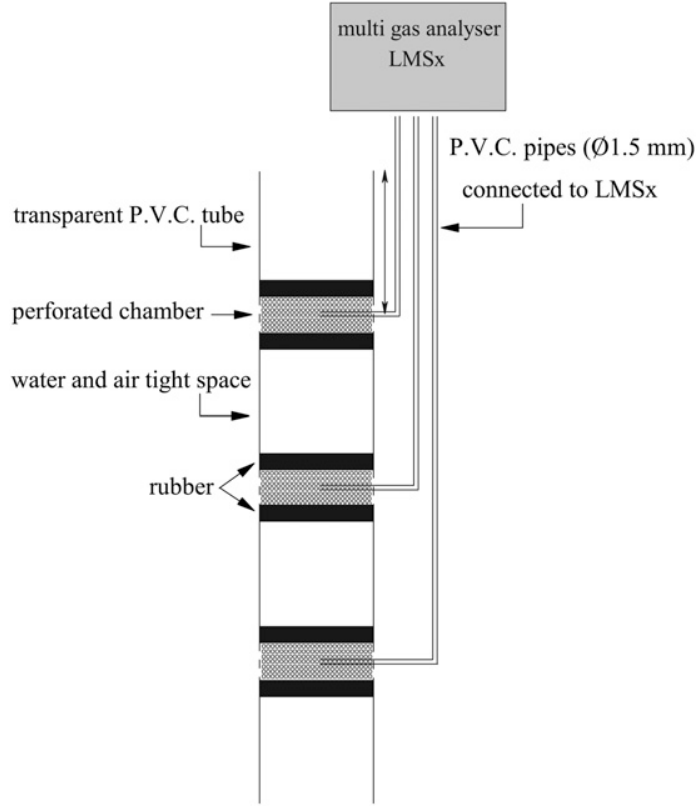

Fig. 2. Section of the air extraction device illustrating the chambers at three different heights with perforated walls connected to the multi gas analyzer LMSx (Eijkelkamp, The Netherlands) through a $1.5-\mathrm{mm}$ diameter transparent polyvinyl chloride tube positioned at the center of each chamber. plant growth and a pressure head less negative than $-10 \mathrm{~cm}$ produces inadequate substrate aeration for plant growth. The experimental drying and wetting retention curves of the substrates depicted in Figure 3 ranged between 0 and $-180 \mathrm{~cm}$ pressure heads (i.e., within and beyond the thresholds defined by De Boodt and Verdonck, 1972) providing important information with regard to plant growth. The main hydraulic characteristics of the substrates derived from the water retention curves are presented in Table 1.

As shown in Table $1, \mathrm{Ps}_{60}: \mathrm{Pb}_{30}: \mathrm{P}_{10}$ had the highest total porosity, container capacity, easily available water, and air-filled porosity (at water tension $-50 \mathrm{~cm}$ ) than all the other substrates used. On the other hand, $\mathrm{C}_{50}: \mathrm{P}_{50}$ had the lowest total porosity, container capacity, and easily available water. However, $\mathrm{C}_{50}: \mathrm{P}_{50}$ had the highest airspace (air-filled porosity at container capacity). With regard to peat-perlite mixtures, as the percentage of perlite increased from $25 \%$ to $50 \%$, the total porosity and container capacity decreased and the air-filled porosity increased slightly.

As shown in Figure 3, hysteresis was most pronounced in the peat-based substrate
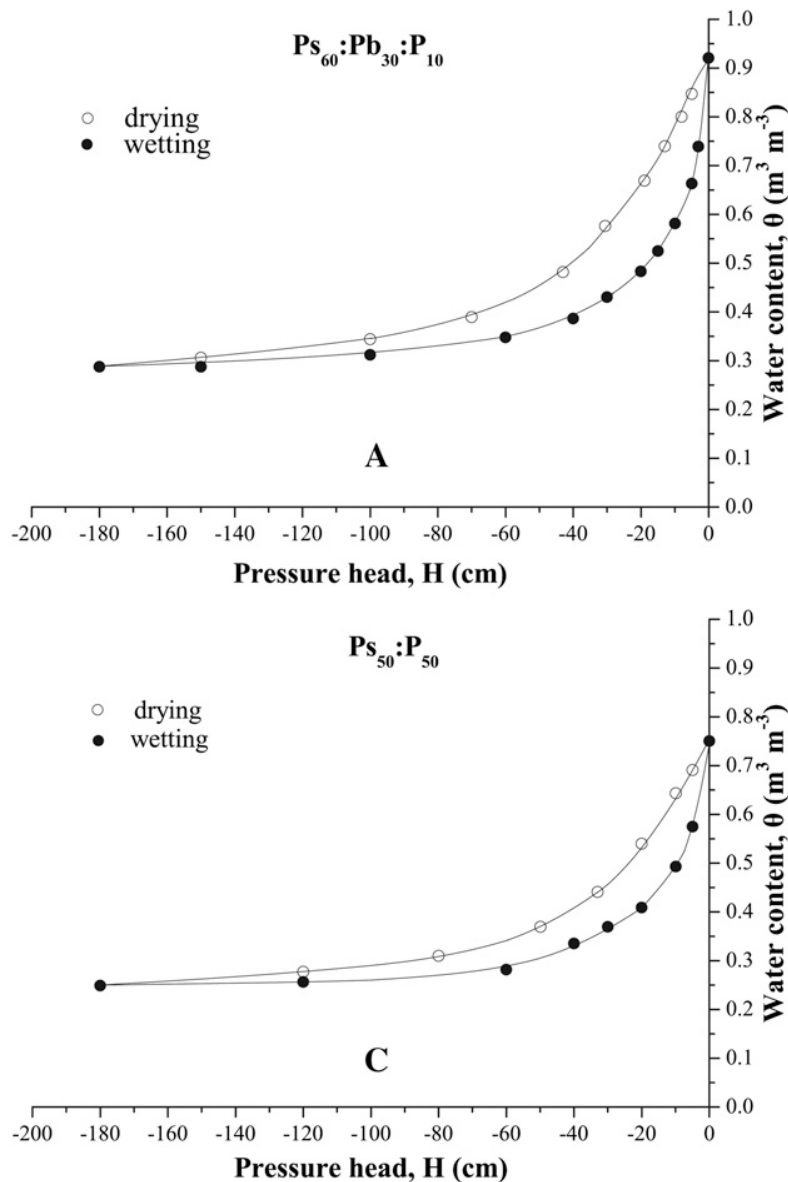

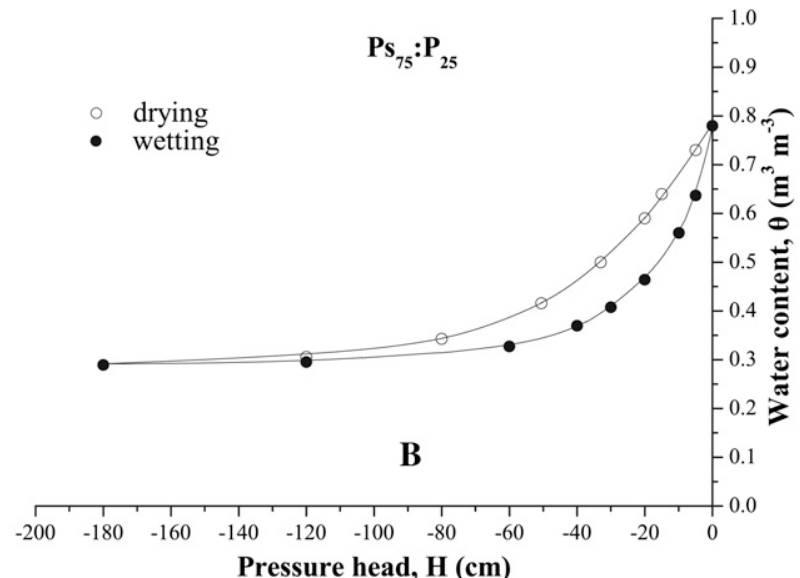

Pressure head, $\mathrm{H}(\mathrm{cm})$

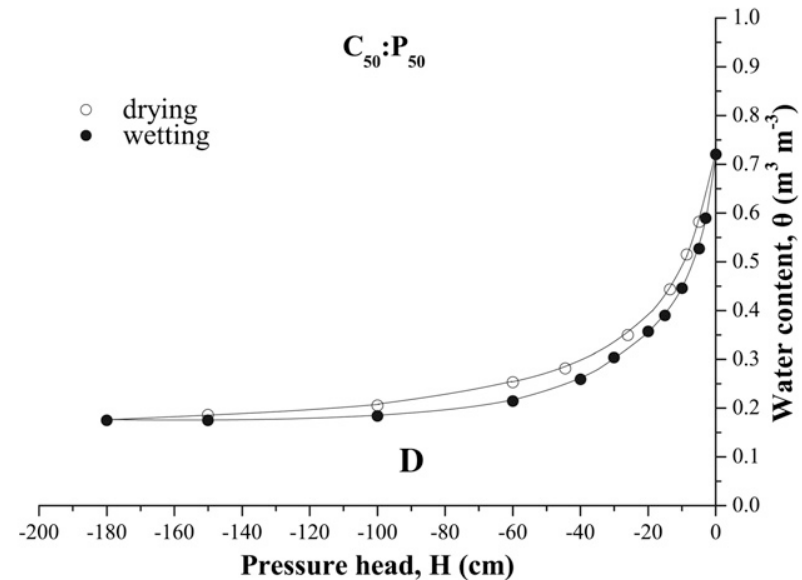

Fig. 3. Water retention curves during drying and wetting for the substrates: 1) sphagnum peat, black peat, and perlite mixture at a proportion of 60:30:10 $\left.(\mathrm{v} / \mathrm{v})\left(\mathrm{Ps}_{60}: \mathrm{Pb}_{30}: \mathrm{P}_{10}\right) ; 2\right)$ sphagnum peat and perlite mixture at a proportion of $\left.75: 25(\mathrm{v} / \mathrm{v})\left(\mathrm{Ps}_{75}: \mathrm{P}_{25}\right) ; 3\right)$ sphagnum peat and perlite mixture at a proportion of 50:50 (v/v) $\left(\mathrm{Ps}_{50}: \mathrm{P}_{50}\right)$; and 4) coir and perlite mixture at a proportion of 50:50 (v/v) $\left(\mathrm{C}_{50}: \mathrm{P}_{50}\right)$. Values are means of three replications $(\mathrm{n}=3)$. 
mixtures. This phenomenon may be influenced by peat hydrophobicity (Naasz et al., 2008). The maximum hysteretic difference (between points on the drying and wetting curves having the same value of pressure head) relative to the value on the wetting curve is $\approx 36 \%$ for $\mathrm{Ps}_{60}: \mathrm{Pb}_{30}: \mathrm{P}_{10}, 30 \%$ for $\mathrm{Ps}_{50}: \mathrm{P}_{50}, 27 \%$ for $\mathrm{Ps}_{75}: \mathrm{P}_{25}$, and $19 \%$ for $\mathrm{C}_{50}: \mathrm{P}_{50}$ in the water retention curve.

With regard to particle size distribution, the peat-perlite mixtures were characterized by a higher percentage of particles greater than $4 \mathrm{~mm}$ and a lower percentage $(\approx 27 \%)$ of particles less than $1 \mathrm{~mm}$ compared with the other two substrates studied (Table 2). However, despite the increase in the percentage of perlite from $25 \%$ to $50 \%$, differences in particle size distribution and consequently in the physical properties were small (Table 1; Fig. 3). On the other hand, $\mathrm{C}_{50}: \mathrm{P}_{50}$ was characterized by a low percentage $(\approx 5 \%)$ of particle sizes greater than $4 \mathrm{~mm}$ and a high percentage of particle sizes ranging between 4 and $1 \mathrm{~mm}(\approx 53 \%)$ and particle sizes less than $1 \mathrm{~mm}(\approx 42 \%)$, whereas $\mathrm{Ps}_{60}: \mathrm{Pb}_{30}: \mathrm{P}_{10}$ was characterized by a high percentage ( $\approx 77 \%$ ) of particle sizes less than $1 \mathrm{~mm}$. This variation of the substrate particle sizes led to differences in substrate aeration and other physical properties (Tables 1 and 2).

The bulk density values of the substrates $\mathrm{Ps}_{75}: \mathrm{P}_{25}, \mathrm{Ps}_{50}: \mathrm{P}_{50}, \mathrm{C}_{50}: \mathrm{P}_{50}$, and $\mathrm{Ps}_{60}: \mathrm{Pb}_{30}: \mathrm{P}_{10}$ were $0.100 \mathrm{~g} \cdot \mathrm{cm}^{-3}, 0.116 \mathrm{~g} \cdot \mathrm{cm}^{-3}, 0.094 \mathrm{~g} \cdot \mathrm{cm}^{-3}$, and $0.104 \mathrm{~g} \cdot \mathrm{cm}^{-3}$, respectively (Table 1 ). As shown, all the substrates studied have low values of bulk density.
Substrate water profiles. Throughout the experiment, water profiles were determined to assess the moisture condition of the substrates between successive irrigations and to determine the daily water requirements of the plants. Indicatively, the water profiles between two successive irrigations of plants, halfway through plant growth in the large pots, are shown in Figure 4. Specifically, representative water profiles are given during the time period 13 Jan. to $15 \mathrm{Jan}$. after receiving irrigation on $12 \mathrm{Jan}$. with $200 \mathrm{~cm}^{3}$ water. The following irrigation was performed on 15 Jan. after the corresponding water profiles were determined. As shown in Figure 4 , the water content of the substrate is greater and accordingly the air content is less in substrates of pots irrigated with drip irrigation than with capillary mat sub-irrigation. In all substrates, irrespective of the watering regime, the evapotranspiration between consecutive water profiles fluctuated between 1.4 $\mathrm{mm} \cdot \mathrm{d}^{-1}$ (determined between the water profiles taken on 13 Jan. and 14 Jan.) and 1.8 $\mathrm{mm} \cdot \mathrm{d}^{-1}$ (determined between the water profiles taken on 14 Jan. and 15 Jan.) (data not shown).

Substrate oxygen concentration. In general the $\mathrm{O}_{2}$ concentration of the substrates studied irrespective of pot size, substrate type, and watering regime was greater than $20.4 \%$. However, the $\mathrm{O}_{2}$ concentration along the depth of the substrates varied with pot size (data not shown).

In the case of the small pots, for all substrates and both irrigation systems applied,

Table 1. Hydraulic characteristics of the substrates: 1) sphagnum peat and perlite mixture at a proportion of 75:25 (v/v) $\left.\left(\mathrm{Ps}_{75}: \mathrm{P}_{25}\right) ; 2\right)$ sphagnum peat and perlite mixture at a proportion of 50:50 (v/v) $\left(\mathrm{Ps}_{50}: \mathrm{P}_{50}\right)$;

3) sphagnum peat, black peat, and perlite mixture at a proportion of $60: 30: 10(\mathrm{v} / \mathrm{v})\left(\mathrm{Ps}_{60}: \mathrm{Pb}_{30}: \mathrm{P}_{10}\right)$; and 4) coir and perlite mixture at a proportion of 50:50 (v/v) $\left(\mathrm{C}_{50}: \mathrm{P}_{50}\right)^{\mathrm{z}}$

\begin{tabular}{lcccccc}
\hline Substrate & $\begin{array}{c}\text { Total } \\
\text { porosity }^{y}(\%)\end{array}$ & $\begin{array}{c}\text { Airspace } \\
(\%)\end{array}$ & $\begin{array}{c}\text { Container } \\
\text { capacity }^{\mathrm{w}} \\
(\%)\end{array}$ & $\begin{array}{c}\text { Easily } \\
\text { available } \\
\text { water }^{\mathrm{v}}(\%)\end{array}$ & $\begin{array}{c}\text { Air-filled } \\
\text { porosity } \\
(\text { at }-50 \mathrm{~cm})(\%)\end{array}$ & $\begin{array}{c}\text { Bulk } \\
\text { density } \\
\left(\mathrm{g} \cdot \mathrm{cm}^{-3}\right)\end{array}$ \\
\hline $\mathrm{Ps}_{75}: \mathrm{P}_{25}$ & 78.0 & 10.0 & 68.0 & 26.4 & 36.4 & 0.100 \\
$\mathrm{Ps}_{50}: \mathrm{P}_{50}$ & 75.0 & 10.7 & 64.3 & 27.3 & 38.0 & 0.116 \\
$\mathrm{Ps}_{60}: \mathrm{Pb}_{30}: \mathrm{P}_{10}$ & 92.0 & 13.5 & 78.5 & 33.2 & 46.7 & 0.104 \\
$\mathrm{C}_{50}: \mathrm{P}_{50}$ & 72.0 & 23.0 & 49.0 & 22.0 & 45.0 & 0.094 \\
\hline
\end{tabular}

${ }^{\mathrm{z}}$ Values are the means of three replications $(\mathrm{n}=3)$.

${ }^{\mathrm{y}}$ The water content at $0 \mathrm{~cm}$ pressure head (saturation).

${ }^{x}$ The air-filled porosity at $-10 \mathrm{~cm}$ pressure head.

whe water content at $-10 \mathrm{~cm}$ pressure head.

${ }^{v}$ The amount of water released between pressure heads of -10 and $-50 \mathrm{~cm}$.

Table 2. Particle size distribution of the substrates: 1) sphagnum peat and perlite mixture at a proportion of 75:25 (v/v) $\left.\left(\mathrm{Ps}_{75}: \mathrm{P}_{25}\right) ; 2\right)$ sphagnum peat and perlite mixture at a proportion of 50:50 $(\mathrm{v} / \mathrm{v})\left(\mathrm{Ps}_{50}: \mathrm{P}_{50}\right)$; 3) sphagnum peat, black peat, and perlite mixture at a proportion of 60:30:10 (v/v) $\left(\mathrm{Ps}_{60}: \mathrm{Pb}_{30}: \mathrm{P}_{10}\right)$; and 4) coir and perlite mixture at a proportion of $50: 50(\mathrm{v} / \mathrm{v})\left(\mathrm{C}_{50}: \mathrm{P}_{50}\right){ }^{\mathrm{z}}$

\begin{tabular}{lcccr}
\hline & \multicolumn{4}{c}{ Particle size distribution $(\%$ by wt) } \\
\cline { 2 - 5 } Particle size $(\mathrm{mm})$ & $\mathrm{Ps}_{75}: \mathrm{P}_{25}$ & $\mathrm{Ps}_{50}: \mathrm{P}_{50}$ & $\mathrm{Ps}_{60}: \mathrm{Pb}_{30}: \mathrm{P}_{10}$ & $\mathrm{C}_{50}: \mathrm{P}_{50}$ \\
\hline 8.00 & 5.97 & 4.51 & 1.93 & 0.00 \\
$8.00-4.00$ & 17.77 & 13.75 & 2.95 & 4.87 \\
$4.00-2.00$ & 34.40 & 31.93 & 6.49 & 27.50 \\
$2.00-1.00$ & 15.07 & 21.85 & 11.81 & 25.89 \\
$1.00-0.50$ & 12.57 & 11.22 & 24.90 & 19.29 \\
$0.50-0.25$ & 6.51 & 7.18 & 21.83 & 12.79 \\
$0.25-0.125$ & 3.43 & 3.94 & 15.65 & 5.26 \\
$0.125-0.068$ & 2.23 & 2.72 & 9.08 & 2.20 \\
$<0.068$ & 2.06 & 2.90 & 5.37 & 2.20 \\
\hline
\end{tabular}

${ }^{\mathrm{z}}$ Values are the means of three replications $(\mathrm{n}=3)$. there was no significant difference in $\mathrm{O}_{2}$ concentration along the depth of the pot as a result of the small pot height. The mean $\mathrm{O}_{2}$ concentration value of the small pots was $20.7 \%$.

In the case of the large pots, for dripirrigated substrates, the $\mathrm{O}_{2}$ concentration at the lowest section of the substrates (at $5 \mathrm{~cm}$ height from the base) was $20.4 \%$ and less than in the higher section of the substrates (at $15 \mathrm{~cm}$ height from the base), which was $20.6 \%$ for all substrates studied (data not shown), whereas for sub-irrigated substrates, there was no significant difference of $\mathrm{O}_{2}$ concentration along pot depth and the mean $\mathrm{O}_{2}$ concentration value was $20.5 \%$ for all substrates studied (data not shown).

In general, similar results were obtained by Argo et al. (1996) in their effort to investigate the effect of drip or sub-irrigation on the $\mathrm{O}_{2}$ concentration of three different substrates for growing Chrysanthemum. There were no significant differences between the different irrigation methods applied. Specifically, the $\mathrm{O}_{2}$ concentration of drip-irrigated substrates was slightly decreased throughout the depth of the substrate, whereas the $\mathrm{O}_{2}$ concentration of sub-irrigated substrates was unchanged.

Substrate oxygen diffusion rate. Results of substrate $\mathrm{O}_{2}$ diffusion rate were similar to those obtained for the substrate $\mathrm{O}_{2}$ concentration (Table 3). A decrease in the $\mathrm{O}_{2}$ diffusion rate from the surface to the base of the container is shown in all substrates of the large pots as a result of the increase in moisture associated with closer proximity to the base of the substrate, therefore the decrease in porosity filled with air in which diffusion occurs (Table 3, letters written in italics). Specifically, differences were shown between the lowest $(1 \mathrm{~cm})$ and both higher sections $(6 \mathrm{~cm}$ and $11 \mathrm{~cm}$ ) of the $\mathrm{O}_{2}$ diffusion rate of the drip-irrigated $\mathrm{Ps}_{75}: \mathrm{P}_{25}, \mathrm{Ps}_{50}: \mathrm{P}_{50}$ and $\mathrm{C}_{50}: \mathrm{P}_{50}$ substrates and the sub-irrigated $\mathrm{C}_{50}: \mathrm{P}_{50}$ substrate. Furthermore, significant differences were shown between the lowest $(1 \mathrm{~cm})$ and highest $(11 \mathrm{~cm})$ section for the $\mathrm{O}_{2}$ diffusion rate of the drip-irrigated $\mathrm{Ps}_{60}: \mathrm{Pb}_{30}: \mathrm{P}_{10}$ substrate and sub-irrigated $\mathrm{Ps}_{75}: \mathrm{P}_{25}, \mathrm{Ps}_{50}: \mathrm{P}_{50}$, and $\mathrm{Ps}_{60}: \mathrm{Pb}_{30}: \mathrm{P}_{10}$ substrates (Table 3 ).

As for substrate type, greater values of $\mathrm{O}_{2}$ diffusion rate were shown for the substrate $\mathrm{Ps}_{60}: \mathrm{Pb}_{30}: \mathrm{P}_{10}$. Results showed that the $\mathrm{O}_{2}$ diffusion rate of the drip- or sub-irrigated $\mathrm{Ps}_{60}: \mathrm{Pb}_{30}: \mathrm{P}_{10}$ was significantly greater than the other substrate types at all the heights studied (Table 3). This is the result of the substrate's particle size distribution producing a pore size distribution that developed, among the other substrates studied, the highest total porosity with both high air-filled porosity at container capacity (airspace 13.5\%) and airfilled porosity at water tension $-50 \mathrm{~cm}(46.7 \%)$.

With regard to the irrigation method applied, greater values of $\mathrm{O}_{2}$ diffusion rate were measured in substrates of sub-irrigated pots than in drip-irrigated pots (Table 3 ) as a result of the greater air-filled porosity of the subirrigated substrates.

In general, the $\mathrm{O}_{2}$ diffusion rate values in the current study were 2- to 5-fold 

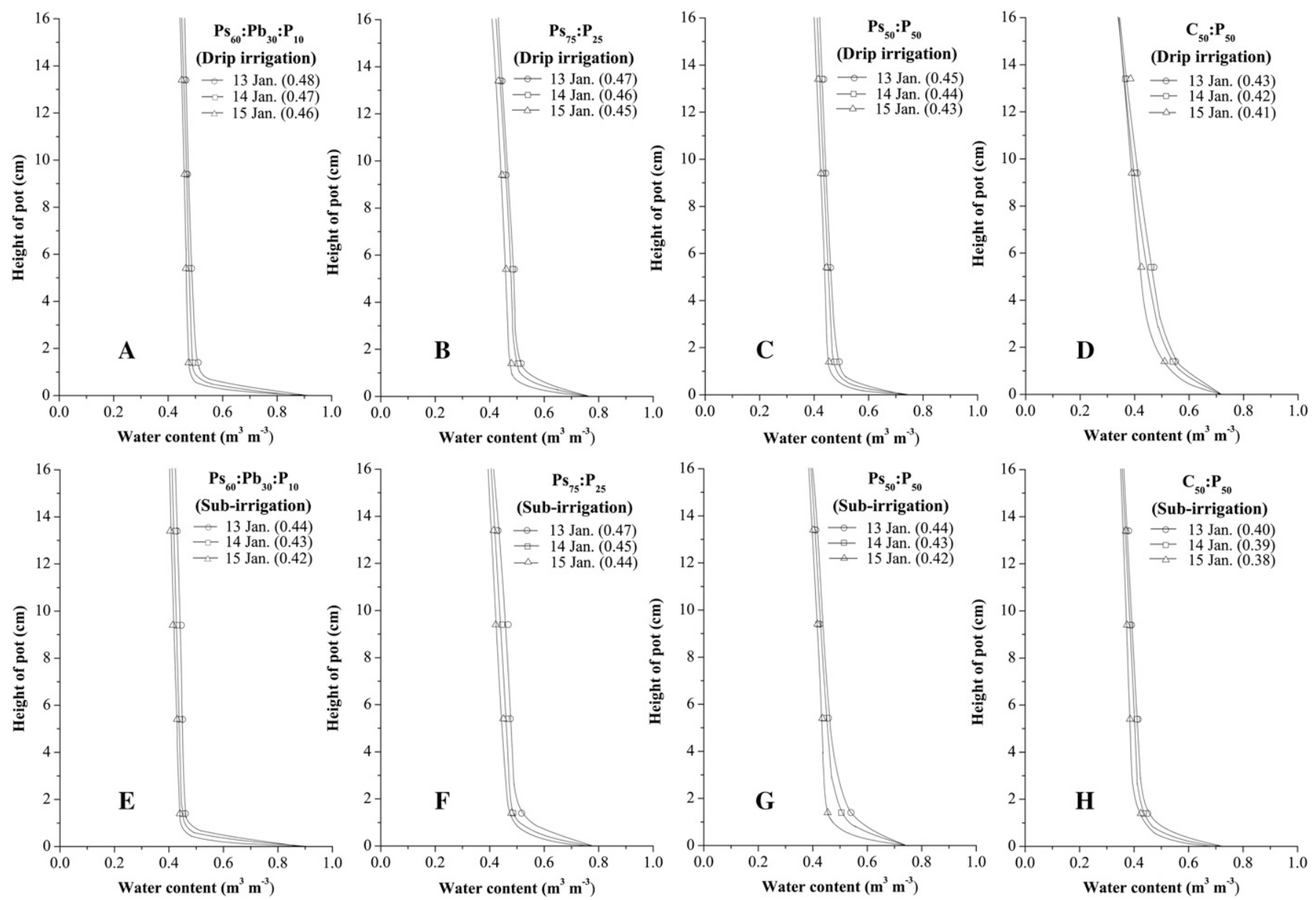

Fig. 4. Water profiles between two successive irrigations of plants halfway through plant growth in the large pots (13 Jan. to 15 Jan.) of the substrates: 1) sphagnum peat, black peat, and perlite mixture at a proportion of 60:30:10 (v/v) $\left.\left(\mathrm{Ps}_{60}: \mathrm{Pb}_{30}: \mathrm{P}_{10}\right) ; 2\right)$ sphagnum peat and perlite mixture at a proportion of $75: 25(\mathrm{v} / \mathrm{v})$ $\left.\left(\mathrm{Ps}_{75}: \mathrm{P}_{25}\right) ; 3\right)$ sphagnum peat and perlite mixture at a proportion of 50:50 (v/v) $\left(\mathrm{Ps}_{50}: \mathrm{P}_{50}\right) ;$ and 4$)$ coir and perlite mixture at a proportion of 50:50 $(\mathrm{v} / \mathrm{v})$ $\left(\mathrm{C}_{50}: \mathrm{P}_{50}\right)$. The value in parentheses is the mean averaged water content of the substrate.

Table 3. Oxygen diffusion rate of substrates: 1) sphagnum peat and perlite mixture at a proportion of 75:25 $\left.(\mathrm{v} / \mathrm{v})\left(\mathrm{Ps}_{75}: \mathrm{P}_{25}\right) ; 2\right)$ sphagnum peat and perlite mixture at a proportion of 50:50 (v/v) $\left.\left(\mathrm{Ps}_{50}: \mathrm{P}_{50}\right) ; 3\right)$ sphagnum peat, black peat, and perlite mixture at a proportion of 60:30:10 (v/v) $\left(\mathrm{Ps}_{60}: \mathrm{Pb}_{30}: \mathrm{P}_{10}\right) ;$ and 4$)$ coir and perlite mixture at a proportion of 50:50 (v/v) $\left(\mathrm{C}_{50}: \mathrm{P}_{50}\right)$ at 1,6 , and $11 \mathrm{~cm}$ height from the base of the pots.

\begin{tabular}{|c|c|c|c|c|}
\hline \multirow[b]{3}{*}{ Irrigation method } & \multirow[b]{3}{*}{ Substrate } & \multicolumn{3}{|c|}{ Oxygen diffusion rate $\left(\mu \mathrm{g} \mathrm{O}_{2} \mathrm{~cm}^{-2} \cdot \mathrm{min}^{-1}\right)$} \\
\hline & & \multicolumn{3}{|c|}{ Ht } \\
\hline & & $1 \mathrm{~cm}$ & $6 \mathrm{~cm}$ & $11 \mathrm{~cm}$ \\
\hline \multirow[t]{4}{*}{ Drip irrigation } & $\mathrm{Ps}_{75}: \mathrm{P}_{25}$ & $0.53 \mathrm{~b}^{\mathrm{z}} b^{\mathrm{y}}$ & $0.62 \mathrm{~b} a$ & $0.70 \mathrm{~b} a$ \\
\hline & $\mathrm{Ps}_{50}: \mathrm{P}_{50}$ & $0.51 \mathrm{~b} b$ & $0.61 \mathrm{~b} a$ & $0.66 \mathrm{~b} a$ \\
\hline & $\mathrm{Ps}_{60}: \mathrm{Pb}_{30}: \mathrm{P}_{10}$ & 0.82 a $b$ & 0.88 a $b$ & $0.97 \mathrm{a} a$ \\
\hline & $\mathrm{C}_{50}: \mathrm{P}_{50}$ & $0.41 \mathrm{c} c$ & $0.57 \mathrm{~b} b$ & $0.69 \mathrm{~b} a$ \\
\hline \multirow[t]{4}{*}{ Sub-irrigation } & $\mathrm{Ps}_{75}: \mathrm{P}_{25}$ & $0.55 \mathrm{~b} b$ & $0.64 \mathrm{~b} a b$ & $0.72 \mathrm{~b} a$ \\
\hline & $\mathrm{Ps}_{50}: \mathrm{P}_{50}$ & $0.53 \mathrm{~b} b$ & $0.64 \mathrm{~b} a b$ & $0.72 \mathrm{~b} a$ \\
\hline & $\mathrm{Ps}_{60}: \mathrm{Pb}_{30}: \mathrm{P}_{10}$ & 0.88 a $b$ & 0.96 a $a b$ & $1.05 \mathrm{a} a$ \\
\hline & $\mathrm{C}_{50}: \mathrm{P}_{50}$ & $0.50 \mathrm{bc} b$ & $0.62 \mathrm{~b} a$ & $0.71 \mathrm{~b} a$ \\
\hline
\end{tabular}

${ }^{2}$ In each column values not followed by the same letter are significant (comparison of means by TukeyKramer at $P=0.05 ; \mathrm{n}=10$ ).

'In each row values not followed by the same letter written in italics are significant (comparison of means by Tukey-Kramer at $P=0.05 ; \mathrm{n}=10$ ).

greater than the value $0.2 \mu \mathrm{g} \mathrm{O} \mathrm{Cm}^{-2} \cdot \mathrm{min}^{-1}$, which is considered critical for the root growth of plants in soils (Letey and Stolzy, 1967; Sojka and Stolzy, 1980; Stolzy and Letey, 1964). Paul and Lee (1976) also found that the growth of chrysanthemums within 13 different substrates increased within the range of 0.05 to $0.65 \mu \mathrm{g} \mathrm{O}_{2}$ $\mathrm{cm}^{-2} \cdot \mathrm{min}^{-1}$ that is 3 -fold greater than the aforementioned critical value for root growth of plants in soils. These results were to be expected because pot plants growing in a greenhouse have much higher root densities, nutrient levels, and growth rates than field crops, so their requirements for $\mathrm{O}_{2}$ would also be much higher.

Plant growth. Both $\mathrm{Ps}_{60}: \mathrm{Pb}_{30}: \mathrm{P}_{10}$ drip- and sub-irrigated plants were significantly greater than the plants of the other irrigation-substrate type combinations in height, number of flowers, and shoot dry weight (Table 4). Although all plants in all substrates received the same fertilizer treatment, substrate $\mathrm{Ps}_{60}: \mathrm{Pb}_{30}: \mathrm{P}_{10}$ was the only substrate enriched with nutrients by the manufacturer. Therefore, as a result of differences in the original nutrient content among substrates, the results based on shoot or root growth are inconclusive for plants showing better growth in substrate $\mathrm{Ps}_{60}: \mathrm{Pb}_{30}: \mathrm{P}_{10}$. Consequently, the results concerning the plant growth of the fortified substrate $\mathrm{Ps}_{60}: \mathrm{Pb}_{30}: \mathrm{P}_{10}$ are not included in the following results and discussion concerning the plant growth of the other substrates.

With regard to the root development of drip-irrigated plants, plants grown in $\mathrm{Ps}_{75}: \mathrm{P}_{25}$ and $\mathrm{P}_{50}: \mathrm{P}_{50}$ developed a vigorous root system that consisted of many root hairs mainly toward the walls of the pots but throughout their entire depth (data not shown). Plants grown in $\mathrm{C}_{50}: \mathrm{P}_{50}$ developed a root system that consisted of larger diameter roots and much less root hairs compared with the other substrates (data not shown). On the other hand, the root system of plants that were subirrigated developed mainly at the base of the 
Table 4. Plant height, number of flowers, shoot and root dry weights at the end of the experiment, and percent growth increase $(\%)$ of begonia plants throughout the duration of the experiment as affected by the combined effect of irrigation and substrate type: 1) sphagnum peat and perlite mixture at a proportion of 75:25 (v/v) $\left.\left(\mathrm{Ps}_{75}: \mathrm{P}_{25}\right) ; 2\right)$ sphagnum peat and perlite mixture at a proportion of 50:50 $(\mathrm{v} / \mathrm{v})$ $\left(\mathrm{Ps}_{50}: \mathrm{P}_{50}\right)$; 3) sphagnum peat, black peat, and perlite mixture at a proportion of $60: 30: 10(\mathrm{v} / \mathrm{v})$ $\left(\mathrm{Ps}_{60}: \mathrm{Pb}_{30}: \mathrm{P}_{10}\right)$; and 4) coir and perlite mixture at a proportion of 50:50 (v/v) $\left(\mathrm{C}_{50}: \mathrm{P}_{50}\right)$.

\begin{tabular}{lllcccc}
\hline Irrigation method & \multicolumn{1}{c}{$\begin{array}{c}\text { Substrate } \\
\text { Drip irrigation }\end{array}$} & $\begin{array}{c}\text { Plant } \\
\text { ht }(\mathrm{cm})\end{array}$ & $\begin{array}{c}\text { Number of } \\
\text { flowers }\end{array}$ & $\begin{array}{c}\text { Shoot dry } \\
\mathrm{wt}(\mathrm{g})\end{array}$ & $\begin{array}{c}\text { Root dry } \\
\mathrm{wt}(\mathrm{g})\end{array}$ & $\begin{array}{c}\text { Percent growth } \\
\text { increase }(\%)\end{array}$ \\
\hline & $\mathrm{Ps}_{75}: \mathrm{P}_{25}$ & $24.9 \mathrm{~b}^{\mathrm{z}}$ & $97 \mathrm{~b}$ & $15.4 \mathrm{~b}$ & $9.6 \mathrm{abc}$ & $90.1 \mathrm{ab}$ \\
& $\mathrm{Ps}_{50}: \mathrm{P}_{50}$ & $25.6 \mathrm{~b}$ & $107 \mathrm{~b}$ & $16.7 \mathrm{~b}$ & $10.3 \mathrm{ab}$ & $91.1 \mathrm{ab}$ \\
& $\mathrm{Ps}_{60}: \mathrm{Pb}_{30}: \mathrm{P}_{10}$ & $31.6 \mathrm{a}$ & $173 \mathrm{a}$ & $22.6 \mathrm{a}$ & $9.0 \mathrm{abc}$ & $92.1 \mathrm{a}$ \\
Sub-irrigation & $\mathrm{C}_{50}: \mathrm{P}_{50}$ & $23.3 \mathrm{bc}$ & $82 \mathrm{bc}$ & $13.3 \mathrm{~b}$ & $9.3 \mathrm{abc}$ & $89.0 \mathrm{ab}$ \\
& $\mathrm{Ps}_{75}: \mathrm{P}_{25}$ & $21.1 \mathrm{c}$ & $50 \mathrm{~cd}$ & $9.0 \mathrm{c}$ & $6.00 \mathrm{bc}$ & $82.1 \mathrm{~cd}$ \\
& $\mathrm{Ps}_{50}: \mathrm{P}_{50}$ & $20.5 \mathrm{c}$ & $39 \mathrm{~d}$ & $10.0 \mathrm{c}$ & $10.4 \mathrm{a}$ & $86.9 \mathrm{bc}$ \\
& $\mathrm{Ps}_{60}: \mathrm{Pb}_{30}: \mathrm{P}_{10}$ & $32.1 \mathrm{a}$ & $152 \mathrm{a}$ & $20.9 \mathrm{a}$ & $11.5 \mathrm{a}$ & $92.4 \mathrm{a}$ \\
& $\mathrm{C}_{50}: \mathrm{P}_{50}$ & $20.1 \mathrm{c}$ & $41 \mathrm{~d}$ & $7.4 \mathrm{c}$ & $5.8 \mathrm{c}$ & $80.6 \mathrm{~d}$ \\
\hline
\end{tabular}

${ }^{\mathrm{z}}$ Columns not followed by the same letter are significant (Tukey-Kramer, at $P=0.05 ; \mathrm{n}=10$ ).

substrates and consisted of large-diameter roots (data not shown).

The combined effect of irrigation-substrate type showed that the root dry weights of $\mathrm{Ps}_{50}: \mathrm{P}_{50}$ sub-irrigated plants were significantly greater than the corresponding root dry weights of the plants grown in the other types of sub-irrigated substrates (Table 4).

With regard to the combined effect of irrigation-substrate on the percent growth increase of begonias, results showed that all drip-irrigated plants were greater than the subirrigated plants grown in $\mathrm{Ps}_{75}: \mathrm{P}_{25}$ and $\mathrm{C}_{50}: \mathrm{P}_{50}$ (Table 4). The lowest value of percent growth increase was presented in the sub-irrigated $\mathrm{C}_{50}: \mathrm{P}_{50}$ (Table 4). All substrates whether dripor sub-irrigated had adequate amounts of $\mathrm{O}_{2}$ and water content; therefore, it is possible that other factors have contributed to the decreased growth of the sub-irrigated plants such as electrical conductivity (EC) that is known to be increased in sub-irrigated substrates (Handreck and Black, 1994).

To conclude, the results showed that both irrigation treatments (drip- and sub-irrigation system) addressed the water requirements of the plants because the water content of all substrates studied was in the easily available water area (between pressures of $-10 \mathrm{~cm}$ and $-50 \mathrm{~cm})$. Furthermore, the percentages of airfilled porosity were adequate in all substrates irrespective of irrigation treatment. With regard to substrate aeration, both irrigation treatments provided sufficient $\mathrm{O}_{2}$ concentration and $\mathrm{O}_{2}$ diffusion rate. Although results with regard to plant growth were inconclusive for the fortified substrate $\mathrm{Ps}_{60}: \mathrm{Pb}_{30}: \mathrm{P}_{10}$, it is worth pointing out that the $\mathrm{O}_{2}$ diffusion
Heiskanen, J. 1993. Favourable water and aeration conditions for growth media used in containerized tree seedling production: A review. Scand. J. For. Res. 8:337-358.

Heiskanen, J. 1995a. Physical properties of twocomponent growth media based on Sphagnum peat and their implications for plant-available water and aeration. Plant Soil 172:45-54.

Heiskanen, J. 1995b. Water status of sphagnum peat and a peat-perlite mixture in containers subjected to different irrigation regimes. HortScience 30:281-284.

Hilding, A. 1982. Produktion av Begonia ×elatior. Trädgård 220. Swedish University of Agricultural Sciences Research Information Centre, Alnarp, Sweden.

Johnson, P. 1968. Horticultural and agricultural uses of sawdust and soil amendments. Paul Johnson, National City, CA.

Letey, J. and L.H. Stolzy. 1967. Limiting distances between root and gas phase for adequate oxygen supply. Soil Sci. 103:404-409. $\mathrm{Ps}_{60}: \mathrm{Pb}_{30}: \mathrm{P}_{10}$ were significantly greater than those of the other substrate types studied. Although the substrates $\mathrm{Ps}_{75}: \mathrm{P}_{25}, \mathrm{Ps}_{50}: \mathrm{P}_{50}$, and $\mathrm{C}_{50}: \mathrm{P}_{50}$ meet adequately the water-air balance plant needs, the plant growth of the drip-irrigated substrates was greater than in the corresponding sub-irrigated substrates. This could be attributed to the effect of other factors on plant growth such as the effect of EC on sub-irrigated substrates.

\section{Literature Cited}

Arenas, M. and C.S. Vavrina. 1998. Coconut coir medium for tomato transplant production. HortScience 33:549-550.

Argo, W.R., J.A. Biernbaum, and W.C. Fonteno. 1996. Root medium carbon dioxide and oxygen partial pressures for container-grown chrysanthemums. HortScience 31:385-388.

Bunt, A.C. 1988. Media and mixes for containergrown plants. Unwin Hyman, London, UK.

Cresswell, G.C. 1992. Coir dust-A viable alternative to peat? Proc. Austral. Potting Mix Manufacturers Conf., Sydney, Australia. p. 1-5.

De Boodt, M. and O. Verdonck. 1972. The physical properties of the substrates in horticulture. Acta Hort. 26:37-44.

Evans, M.R., S. Konduru, and R.H. Stamps. 1996. Source variation in physical and chemical properties of coconut coir dust. HortScience 31:965-967.

Haines, W.B. 1930. Studies in the physical properties of soils. V. The hysteresis effect in capillary properties and the modes of moisture distribution associated therewith. J. Agric. Sci. 20:97-116.

Handreck, K.A. and N.D. Black. 1994. Growing media for ornamental plant and turf. UNSW Press, Randwick, Australia.
Meerow, A.W. 1994. The potential of coir (coconut mesocarp pith) as a peat substitute in container media. HortScience 29:452.

Molnar, J.M. 1974. Photoperiodic responses of Begonia $\times$ hiemalis cv. 'Rieger'. Con. J. Plant Sci. 54:277-280.

Naasz, R., J.C. Michel, and S. Charpentier. 2008. Water repellency of organic growing media related to hysteretic water retention properties. Eur. J. Soil Sci. 59:156-165.

Nektarios, P.A., I. Amountzias, I. Kokkinou, and N. Ntoulas. 2011a. Green roof substrate type and depth affect the growth of the native species dianthus fruticosus under reduced irrigation regimens. HortScience 46:1208-1216.

Nektarios, P.A., S. Kastritsis, N. Ntoulas, and P. Tsiotsiopoulou. 2011b. Substrate amendment effects on potted plant production and dry weight partition of lantana camara. HortScience 46:864-869.

Nelson, P.V. 2011. Greenhouse operation and management. 7th Ed. Prentice Hall, Englewood Cliffs, NJ

Paul, J.L. and C.I. Lee. 1976. Relation between growth of chrysanthemums and aeration of various container media. J. Amer. Soc. Hort. Sci. 101:500-503.

Puustjärvi, V. 1977. Peat and its use in horticulture, Turveteollisuuslitto r.y. Publication 3. Liikekirjapaino, Helsinki, Finland. p. 160.

Sojka, R.A. and L.H. Stolzy. 1980. Soil-oxygen effects on stomatal response. Soil Sci. 130:350 358.

Stamps, R.H. and M.R. Evans. 1997. Growth of Dieffenbachia maculata 'Camille' in growing media containing sphagnum peat or coconut coir dust. HortScience 32:844-847.

Stolzy, L.H. and J. Letey. 1964. Characterizing soil oxygen conditions with a platinum microelectrode. Adv. Agron. 16:249-279. 